\title{
The Problem of Polypharmacy in Female Patients with Overactive Bladders - Cross-Sectional Study in a Specialist Outpatient Department
}

\author{
Das Problem der Polymedikation bei Patientinnen mit Überaktiver Blase - \\ Querschnittsuntersuchung einer Spezialambulanz
}

Authors

Affiliations

\author{
C. S. Schneidinger ${ }^{1}$, W. Umek ${ }^{1}$, B. Böhmdorfer ${ }^{2}$
}

1 Department of Obstetrics and Gynecology, Medical University of Vienna, Austria, Vienna, Austria

${ }^{2}$ Geriatric Medicine, Paracelsus Medizinische Privatuniversität, Salzburg, Austria

\section{Key words \\ - overactive bladder \\ - polypharmacy \\ - urinary incontinence \\ - drug-drug interactions \\ Schlüsselwörter \\ - Überaktive Blase \\ - Polymedikation \\ - Harninkontinenz \\ - Medikamenteninteraktionen}

Deutsche Version unter: http://dx.doi.org/ $10.1055 / \mathrm{s}-0042-114221$

$\begin{array}{ll}\text { received } & 21.3 .2016 \\ \text { revised } & 2.7 .2016 \\ \text { accepted } & 30.7 .2016\end{array}$

Bibliography

DOI http://dx.doi.org/

10.1055/s-0042-114221

Geburtsh Frauenheilk 2016; 76:

1318-1324 @ Georg Thieme

Verlag KG Stuttgart · New York .

ISSN 0016-5751

\section{Correspondence}

Dr. Cora Sophia Schneidinger

Allgemeines Krankenhaus

der Stadt Wien-Klinikum der

Medizinischen Universitat Wien

Universitätsklinik für

Frauenheilkunde

Währinger Gürtel 18-20

1090 Wien

Austria

cora.schneidinger@gmx.at

\section{Abstract \\ $\nabla$}

Background: The consumption of certain drugs can cause urinary incontinence. The aim of this study is to determine the frequency of consumption of drugs that can favour incontinence, the incidence of polypharmacy and the incidence of potentially dangerous drug-drug interactions in female patients suffering from overactive bladder (OAB) who presented to a urogynaecological outpatient department.

Methods: We undertook a retrospective case series study. The data from 100 female patients who attended the urogynaecological outpatient department of the Vienna General Hospital [VGH; Allgemeinen Krankenhauses Wien (AKH)] in the period from 20.07.2010 to 30.08.2011 were evaluated. The patients suffered either from an $O A B$ or mixed incontinence with predominantly urge components. Among other factors, we were interested in the drugs taken for longer periods of time as well as the general and the urogynaecological case histories. 15 parameters were recorded: age, BMI, menopausal status, parity, pelvic organ prolapse, DIAPPERS criteria (delirium, infection (urinary), atrophic urethritis and vaginitis, pharmaceuticals, psychological disorders (especially depression), excessive urine output, restricted mobility, stool impaction), drug side effects and drug-drug interactions. A descriptive statistical analysis was performed. The drugs were checked with the help of a drug information system (Intranet-KH [V 6.0]). Of particular interest was the consumption of drugs that could favour urinary incontinence as an adverse side effect. In addition the frequency of polypharmacy and the frequency of potentially health-threatening drug combinations were registered.

Results: $57 \%$ of the patients consumed at least one drug that could reinforce urinary incontinence. The frequency of polypharmacy was $38 \%$. In $45 \%$ of the patients the possibility for health-

\section{Zusammenfassung}

$\nabla$

Hintergrund: Die Einnahme bestimmter Medikamente kann die Ursache für Harninkontinenz sein. Das Ziel dieser Studie war die Erhebung der Häufigkeit von Medikamenteneinnahmen, die eine Inkontinenz begünstigen können, die Häufigkeit von Polymedikation sowie die Häufigkeit von potentiell gefährlichen Medikamenteninteraktionen bei Patientinnen einer urogynäkologischen Spezialambulanz, die an Überaktiver Blase (ÜAB) leiden.

Methodik: Wir führten eine retrospektive Fallserie durch. Erfasst wurden die Daten von 100 Patientinnen, die im Zeitraum zwischen 20.07.2010 und 30.08.2011 die urogynäkologische Ambulanz des Allgemeinen Krankenhauses Wien (AKH) aufsuchten. Die Patientinnen litten entweder an einer ÜAB oder an einer Mischinkontinenz mit Überwiegen der Drangkomponente. Unter anderem erhoben wurden die dauerhaft eingenommenen Medikamente, eine allgemeine und eine urogynäkologische Anamnese. 15 Parameter wurden erhoben: Alter, BMI, Menopausenstatus, Parität, Beckenorganprolaps, DIAPPERS-Kriterien (Delirium, Harnwegsinfektion, Atrophie, psychische Faktoren, Pharmakotherapie, exzessive Harnausscheidung, eingeschränkte Mobilität und Obstipation), Medikamentennebenwirkungen und Medikamenteninteraktionen. Eine deskriptive Statistik wurde durchgeführt. Die Überprüfung der Medikamente erfolgte mittels Medikamenteninformationssystem (Intranet-KH [V 6.0]). Von besonderem Interesse war die Einnahme von Medikamenten, die als Nebenwirkung eine Harninkontinenz begünstigen können. Weiters erhoben wurde die Häufigkeit von Polymedikation und die Häufigkeit von potenziell gesundheitsschädigenden Medikamentenkombinationen. Ergebnisse: 57\% der Patientinnen nahmen mindestens ein Medikament ein, das eine Harninkontinenz verstärken kann. Die Häufigkeit von Poly- 
damaging interactions existed as a result of the consumed drugs. Conclusion: The frequencies of consumption of drugs that can favour urinary incontinence and of polypharmacy are high among the patients who attend a specialist outpatient department for urinary incontinence. This emphasises the importance of a complete drug history in the diagnostic work-up for urinary incontinence. medikation betrug 38\%. Bei 45\% der Patientinnen bestand aufgrund der eingenommenen Medikation die Möglichkeit einer gesundheitsschädlichen Medikamenteninteraktion.

Schlussfolgerung: Die Häufigkeit der Einnahme von Medikamenten, die eine Harninkontinenz begünstigen können, und von Polymedikation ist bei Patientinnen, die wegen Harninkontinenz eine Spezialambulanz aufsuchen, hoch. Dies unterstreicht die Wichtigkeit der Medikamentenanamnese im Rahmen der Abklärung von Inkontinenz.

\section{Introduction}

The overactive bladder $(\mathrm{OAB})$ syndrome is a form of incontinence that has a reversible cause in some cases. One of the most important reversible causes is the consumption of drugs. Certain drugs can trigger incontinence as an adverse side effect and also interactions between drugs can favour the occurrence of OAB [1]. This study therefore examines the relationship between polypharmacy and OAB. Of particular interest were the frequency of consumption of drugs with a potential incontinence-promoting activity, the frequency of polypharmacy and an assessment of the frequency of potentially harmful drug-drug interactions in a population of female patients of the Vienna General Hospital who were suffering from $O A B$.

The average prevalence of $\mathrm{OAB}$ among European women aged 40 years or more amounts to $17 \%$ [2]. The prevalence increases with increasing age [2-4]. In the group of over 60-year-olds the prevalence amounts to $45 \%$ [3]. The quality of life of the afflicted persons is appreciably impaired and therapy for overactive bladder syndrome leads to a significant improvement in the quality of life [5].

Polypharmacy is one of the reversible causes of overactive bladder [6]. We speak of polypharmacy when five or more drugs are taken regularly [7]. Numerous drugs can favour urinary incontinence and drug-drug interactions can impact on the lower urinary tract $[3,8]$. Especially elderly persons require polypharmacy [9].

The "overactive bladder" syndrome is defined by the symptom complex pollakiuria ( $\geq 8$ micturitions/24 hours with a normal amount of urine [up to $2.8 \mathrm{l} / 24 \mathrm{~h}$ ]), imperative need to urinate (sudden onset of need to urinate accompanied with the danger of involuntary leakage), nocturia (the awakening from sleep at night to pass urine) as well as premicturitional urine leakage (leakage of urine prior to intended urination) $[6,10,11]$.

The clinical picture of overactive bladder can, but need not, be accompanied with incontinence [10].

In order to make the diagnosis of $\mathrm{OAB}$, possible underlying local, metabolic, neurological or endocrinological pathologies must be excluded [11-13].

\section{Reversible causes}

Since the frequency of urinary incontinence increases with age $[2,4]$ and elderly people above all often suffer from several illnesses that can themselves also trigger the symptom of incontinence, the possibility of a temporary and, in such cases, reversible overactive bladder must be taken into account and checked [14]. The possible causes of reversible incontinence were summarised in 1987 by Resnick with the mnemonic DIAPPERS (diaper) [1]. DIAPPERS is an acronym for the following terms: delirium, (urinary) infection, atrophy of urogenital tract mucous membranes, psychogenic reasons, pharmacotherapy, excessive urinary out- put, restricted mobility and stool masses in the rectum (constipation). All of these factors can lead to an incontinence that, however, can be markedly alleviated or possibly even completely eliminated by successfully addressing these factors [1].

In particular, the impact of drugs that can trigger incontinence as a side effect or by interactions with other drugs should not be underestimated $[8,12]$.

Antihypertensive agents such as diuretics, alpha-receptor blockers, calcium channel blockers, beta-receptor blockers and ACE inhibitors can favour incontinence for various reasons. The mechanisms have been described in many different studies and vary widely. Diuretics increase urine production [15], alpha-receptor blockers reduce the pressure and thus the resistance of the urethra [16], calcium channel blockers lead to polyuria [17] and beta-receptor blockers result in, via a dominance of the parasympathetic nervous system on the detrusor, to an increased contraction readiness of the bladder wall [18]. Also ACE inhibitors can trigger stress incontinence by way of increased coughing that increases the intra-abdominal pressure [19]. Angiotensin-2 blockers have been described as a possible trigger in one study although, according to the authors, also other antihypertensive agents could have been responsible as possible confounding factors [20].

In addition, a relationship between the consumption of oral oestrogens and an increased risk for the occurrence of incontinence has been found, although the exact mechanism is still unknown [21].

Psychoactive drugs (such as sedatives, hypnotics and antidepressants) can lead to so-called overflow incontinence through the two mechanisms - sedation and urinary retention. Anaesthetics lead to constipation and thus to incontinence [22,23]. It is assumed that atypical neuroleptics, by way of an elevated cholinergic stimulation of the detrusor, can lead to a higher micturition frequency and stronger urge to urinate [24,25].

Anticholinergic drugs, antihistamines and tricyclic antidepressants as well as beta-receptor agonists, anticholinergic drugs for Parkinson's disease and levodopa can trigger overflow incontinence though urine retention [18,26,27].

Anticonvulsant agents that reduce bladder outlet resistance and thus facilitate micturition can, under certain circumstances, worsen an already existing incontinence [27].

Certain cholinesterase inhibitors that are used in the treatment of dementia can lead to an increased risk for the occurrence of urinary incontinence through an inhibition of the degradation of acetylcholine which, in turn, causes a stronger activation of the detrusor [28]. Prokinetics can also favour incontinence through so-called detrusor instability [29].

Other drugs associated with urinary incontinence are laxatives and muscle relaxants [23].

- Table 1 summarises the most important drugs that can favour urinary incontinence. 
Also, genital prolapse or, respectively, pelvic organ prolapse (POP) is an independent risk factor for the development of an overactive bladder [30] and was therefore recorded.

The aim of the present study was to record and describe the drug consumption habits of female patients with $\mathrm{OAB}$ in an urogynaecological specialist outpatient department. We examined

1. the incidence of consumption of drugs that favour incontinence,

2. the incidence of polypharmacy and

3. the incidence of disadvantageous drug-drug interactions.

\section{Materials and Methods}

$\nabla$

\section{Study design}

The present study consists of a retrospective case series design. The study was approved by the ethics committee of Vienna Medical University (No. 19/2013).

The data of 100 consecutive female patients who presented to the urogynaecological outpatient unit of the gynaecology department at Vienna General Hospital between 20.07.2010 and 30.08.2011 were recorded. Inclusion criteria were: age of 18 years or more and the diagnoses "overactive bladder" or "mixed incontinence". In cases with the diagnosis "mixed incontinence" the predominance of a strain urinary incontinence component represented an exclusion criterion. Further exclusion criteria were the diagnoses of "pure strain urinary incontinence" and "overflow bladder". The foundations for data collection were the computerised outpatient records in the hospital's own information systems KIS and AKIM.

By means of the stored data the general, gynaecological and urogynaecological case histories including menopausal status, the results of gynaecological and physical examinations as well as DIAPPERS criteria for each and every patient were recorded. All data were extracted from the computerised outpatient files.

Altogether 15 parameters were acquired. These included: age, BMI, menopausal status, parity, pelvic organ prolapse, DIAPPERS criteria (delirium, urinary tract infection, atrophy of the urogenital tract, psychological factors, pharmacotherapy, excessive urine output, restricted mobility and constipation), side effects of the consumed drugs and drug-drug interactions.

Only the DIAPPERS criterion "delirium" could not be extracted from the stored patient records, however, it is assumed that any possible indications for the patient's disorientation would have been documented by the treating physician. The data were entered into a previously prepared data sheet.

If details of medication were lacking, the respective patient was excluded from the study.

The recorded drugs were classified into 35 categories. Each drug was assigned to just one category except when the formulation contained two active substances.

The recorded drugs were evaluated with the help of the drug information system "Medis" (Medis Intranet-KH [V 6.0]). "Medis" is an information system in the Intranet of Vienna General Hospital that provides specialist pharmaceutical information and interaction analyses for drugs. For each drug adverse effects on symptoms that could favour urge incontinence were looked for. These symptoms are pollakiuria, nocturia, incomplete emptying of bladder and urinary incontinence. Each drug exhibiting one or more of these side effects was recorded separately. Furthermore, possible interactions between the drugs taken by an individual were recorded under the function "Rp". All possible interactions
Table 1 Drugs that favour urinary incontinence.

\begin{tabular}{|c|c|c|}
\hline Mechanism & Substance class & Substance name \\
\hline \multirow{6}{*}{$\begin{array}{l}\text { Reduced urethral } \\
\text { pressure }\end{array}$} & alpha-receptor blocker & prazosin \\
\hline & & terazosin \\
\hline & & doxazosin \\
\hline & neuroleptics & haloperidol \\
\hline & & clozapine \\
\hline & oral oestrogens & $\begin{array}{l}\text { oestradiol com- } \\
\text { pounds }\end{array}$ \\
\hline \multirow{4}{*}{$\begin{array}{l}\text { Increased urine } \\
\text { production }\end{array}$} & diuretics & furosemide \\
\hline & & hydrochlorothiazide \\
\hline & calcium antagonists & amlodipine \\
\hline & & diltiazem \\
\hline \multirow[t]{13}{*}{ Detrusor instability } & beta-receptor blocker & carvedilol \\
\hline & prokinetics & bethanechol \\
\hline & & cisapride \\
\hline & antidementia drugs & donepezil \\
\hline & & galantamine \\
\hline & & rivastigmine \\
\hline & $\begin{array}{l}\text { SSRIs (= selective seroto- } \\
\text { nin re-uptake inhibitors) }\end{array}$ & sertraline \\
\hline & & citalopram \\
\hline & & paroxetine \\
\hline & atypical neuroleptics & aripiprazole \\
\hline & & olanzapine \\
\hline & & quetiapine \\
\hline & & risperidone \\
\hline \multirow{18}{*}{$\begin{array}{l}\text { Incomplete bladder } \\
\text { emptying }\end{array}$} & anticholinergic drugs & trospium chloride \\
\hline & & oxybutinin \\
\hline & & tolterodine \\
\hline & & ipratropium bromide \\
\hline & antidepressants & clomipramine \\
\hline & & trazodone \\
\hline & antiparkinson drugs & benzatropine \\
\hline & & trihexyphenidyl \\
\hline & & biperiden \\
\hline & & pramipexole \\
\hline & & L-dopa \\
\hline & & rasagiline \\
\hline & opioids & buprenorphine \\
\hline & & fentanyl \\
\hline & beta-receptor agonists & salbutamol \\
\hline & antihistamines & cetirizine \\
\hline & muscle relaxants & dantrolene \\
\hline & & baclofen \\
\hline \multicolumn{3}{|l|}{ Indirect effects } \\
\hline Coughing & \multicolumn{2}{|c|}{ side effects of ACE inhibitors } \\
\hline Constipation & \multicolumn{2}{|c|}{ side effects of iron, anaesthetics } \\
\hline Sedation & \multicolumn{2}{|c|}{ result/side effects of alcohol, sedatives, anxiolytics } \\
\hline $\begin{array}{l}\text { Oedema and } \\
\text { nocturnal polyuria }\end{array}$ & \multicolumn{2}{|c|}{ NSARs (= non-steroidal antirheumatics) } \\
\hline
\end{tabular}

between drugs were documented and summarised in superordinate categories of the affected organ system. The frequency with which each interaction occurred in the described population was recorded. In addition the frequency with which an individual organ system was affected by drug interactions was analysed.

Furthermore, the drugs consumed by the patients were compared with those on a list compiled in cooperation between a 
Table 2 General patient characteristics.

\begin{tabular}{lc} 
General patient characteristics & Number $\mathbf{n}(\%)$ \\
Age $(\mathrm{n}=100)$ & \\
- age $0-19$ & $1(1 \%)$ \\
- age $20-39$ & $9(9 \%)$ \\
- age $40-59$ & $35(35 \%)$ \\
- age $60-79$ & $49(49 \%)$ \\
- age $80-99$ & $6(6 \%)$ \\
Obesity & \\
- BMI $\left(\mathrm{kg} / \mathrm{m}^{2}\right) \geq 30$ & $25(25 \%)$ \\
- BMI $\left(\mathrm{kg} / \mathrm{m}^{2}\right)<30$ & $46(46 \%)$ \\
- BMI not recorded & $29(29 \%)$ \\
Menopausal status & \\
- pre-menopausal & $22(22 \%)$ \\
- post-menopausal & $73(73 \%)$ \\
- menopausal status not recorded & $5(5 \%)$ \\
Parity & \\
- nulliparous & $16(16 \%)$ \\
- 1 or 2 births & $57(57 \%)$ \\
- $\geq 3$ births & $22(22 \%)$ \\
- parity not recorded & $5(5 \%)$ \\
\hline Pelvic organ prolapse & \\
- prolapse present & $46(46 \%)$ \\
- prolapse beyond vulva level & $17(17 \%)$ \\
- no prolapse present & $53(53 \%)$ \\
- prolapse not recorded & $1(1 \%)$ \\
\hline
\end{tabular}

$\mathrm{BMI}=$ body mass index $\left(\mathrm{kg} / \mathrm{m}^{2}\right)$

group of urogynaecologists and a clinical pharmacologist specialising in geriatric medicine. This list contained drugs that favour urinary incontinence and the responsible mechanisms of action (O Table 1).

\section{Data evaluation}

Descriptive statistics were performed for evaluation of the data. Qualitative data are shown as percentages while average values and standard deviations were calculated for the quantitative data.

\section{Results}

\section{$\nabla$}

We analysed the clinical records of 765 consecutive female patients. Of them 647 were excluded on the basis of their diagnoses, of the 118 patients with the diagnosis OAB 18 were excluded from the analysis because their drug consumption was not or was not completely documented.

The data of 100 patients were evaluated.

\section{Patient characteristics}

Of the 100 patients, $55 \%$ were older than 59 years (average \pm standard deviation: $59 \pm 15$, min: 18 , max: 89$) .73 \%$ were already post-menopausal and $25 \%$ had a BMI $\left(\mathrm{kg} / \mathrm{m}^{2}\right)$ of 30 or more. Genital prolapse or, respectively, pelvic organ prolapse is defined as lowering of the pelvic organs to just a few centimetres above the hymenal border or beyond [31]. In $46 \%$ of the patients a genital prolapse was present although no exact distinctions were made on the type of genital prolapse (uterus prolapse, prolapse of vaginal apex, cystocele or rectocele). $17 \%$ of all patients ( $37 \%$ of all patients with a genital prolapse) had a genital prolapse reaching be- low the hymenal border which was thus designated as a pelvic organ prolapse. 53 patients did not have a genital prolapse. Further patient characteristics are listed in $\bullet$ Table 2.

\section{Drugs}

$83 \%$ of the subjects took at least one drug on a long-term basis. On average each patient took 4 drugs.

Antihypertensives were the most frequently consumed class of drugs. $41 \%$ of the patients took at least one antihypertensive agent per day, the most frequently consumed antihypertensives were beta-receptor blockers ( $18 \%$ of all patients).

The second most frequently consumed class of drugs were hormones. $31 \%$ of the patients regularly took hormones with thyroid hormones and local oestrogens being subsumed.

Antidepressants occupied the third place among the consumed drugs. $29 \%$ of the patients regularly took an antidepressant.

$57 \%$ of all patients took one or more drugs that could trigger or reinforce urinary incontinence ( $\bullet$ Fig. 1$)$. Of these drugs antihypertensives and antidepressants were consumed most frequently.

The pathomechanisms that favour urinary incontinence are listed in Table 1. Most frequently taken were drugs that favour urge incontinence through the mechanism of incomplete bladder emptying. $49 \%$ of all patients consumed at least one drug that impaired complete bladder voiding thereby possibly leading to socalled "overflow incontinence". Above all, drugs with anticholinergic activity that are frequently taken by the elderly often lead, on the one hand, through relaxation of the bladder muscles and, on the other hand, to a central nervous action and tranquilising effects to incomplete bladder emptying. Drugs that can trigger incomplete bladder emptying are antidepressants, neuroleptics, anticholinergic agents, antiparkinson drugs, opioids, antihistamines, prokinetics, beta2-agonists and muscle relaxants [26]. $31 \%$ of all patients consumed drugs that have sedative and constipation-inducing effects and so favour urinary incontinence.

The third most frequent mechanism was increased urine output or polyuria that can occur after consumption of, above all, diuretics or calcium blockers $[15,17]$. $28 \%$ of the patients took drugs that increased the production of urine.

Further side effects of the consumed drugs were nocturia (26\% of the patients) and pollakiuria (22\% of the patients) that can be triggered, above all, by the consumption of antidepressants [32]. - Fig. 2 shows the frequency of consumption of drugs that can favour urinary incontinence as referred to the various age groups. $38 \%$ of the patient took five or more drugs daily. Fig. 3 shows the incidence of polypharmacy referred to five different age groups.

Potentially harmful interactions between the consumed drugs were identified in $45 \%$ of the patients. $17 \%$ of all patients took combinations of drugs with which three or more harmful interactions between the individual drugs could occur.

In $20 \%$ of all patients interactions that could have an effect on blood pressure were identified. The most frequent possible interaction in this collective (15\% of the entire collective) was a weakening of the blood pressure-lowering action of one drug by another.

Equally frequent (20\%) were interactions that could have a reinforcing or a weakening effect on the action of certain other drugs. Most common was the simultaneous consumption of drugs that could reduce the action of thyroid hormone replacement drugs such as, for example, iron and calcium formulations. 


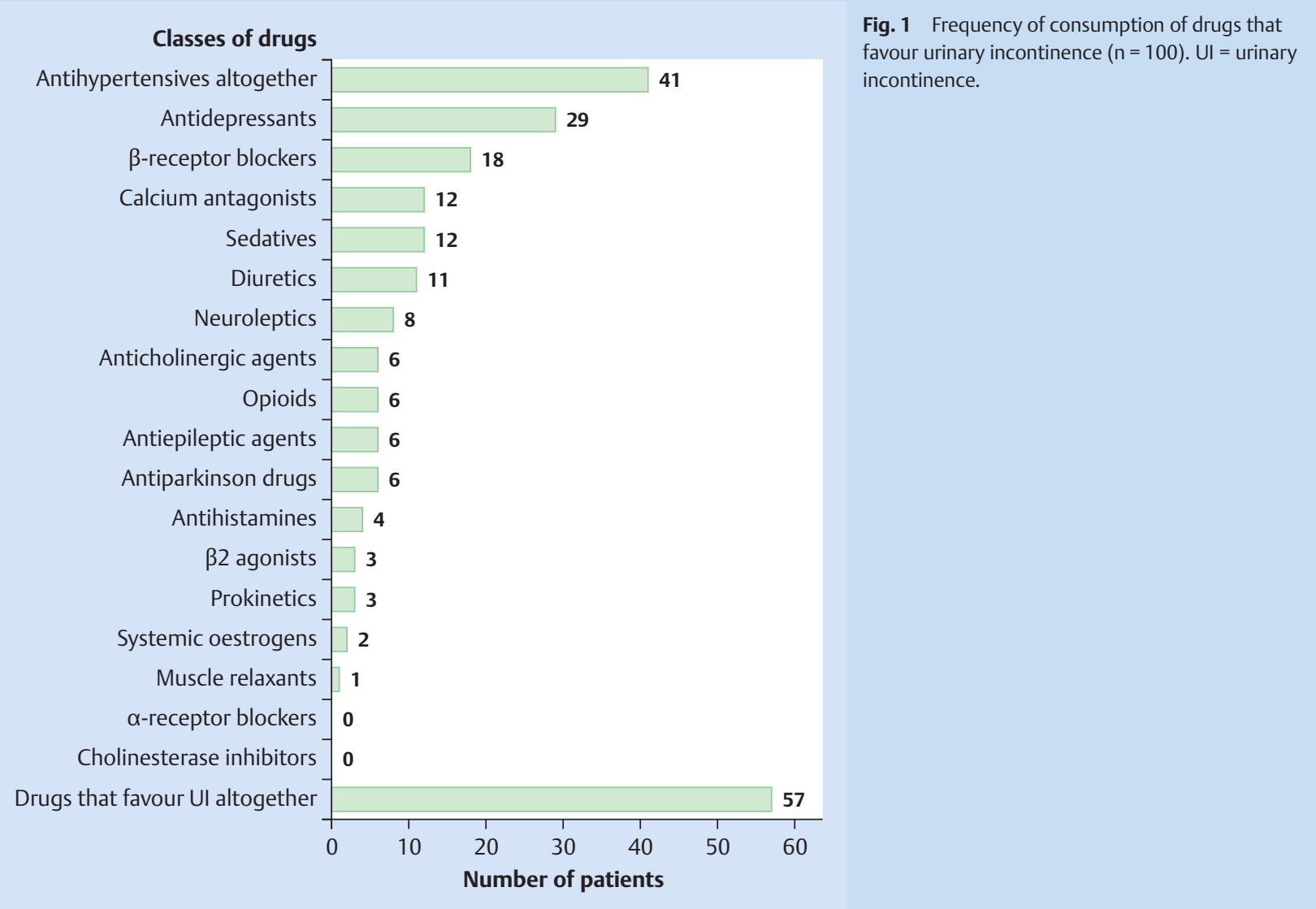

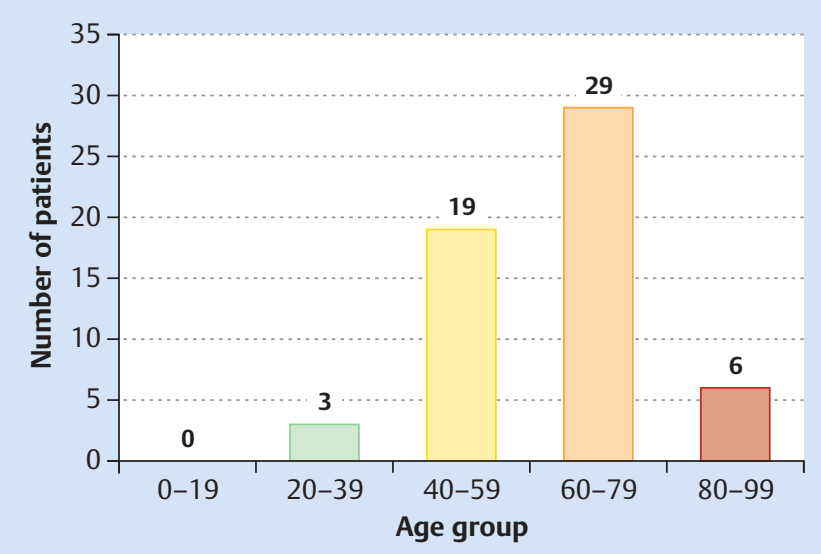

Fig. 2 Frequency of urinary incontinence favouring drugs, referred to age $(n=100)$.

$12 \%$ of the patients took drug combinations that could have a strong effect on the coagulation system. The most probable effect was the possibility of a stronger anticoagulation and thus an increased risk for gastrointestinal bleeding. The combination that was most frequently the reason for a higher risk of bleeding in this collective was the simultaneous consumption of antiplatelet medicines such as Thrombo Ass (aspirin, ASA) or Plavix (clopidogrel) with serotonin re-uptake inhibitors such as Duloxetin, Sertralin or Escitalopram.

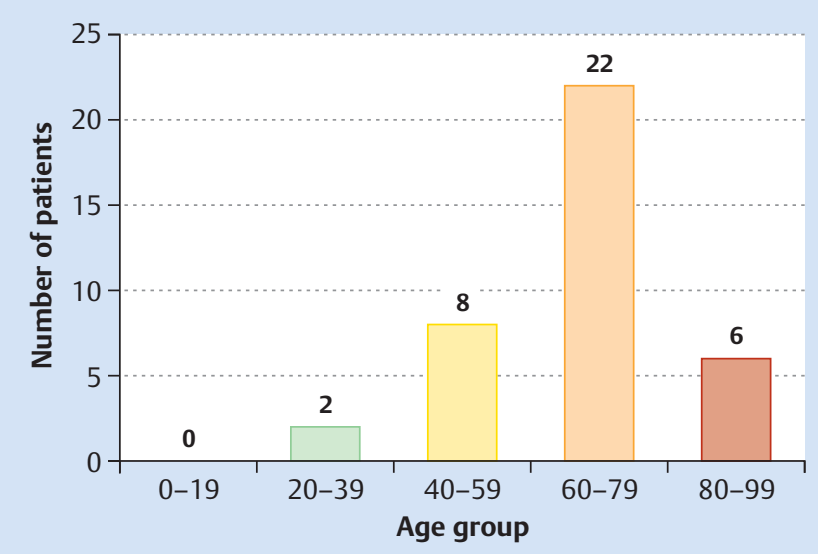

Fig. 3 Incidence of polypharmacy referred to age $(n=100)$. Polypharmacy $=$ consumption of 5 or more drugs.

Further harmful drug combinations can affect the heart through their intensified cardiodepressive activity with an increased danger for the occurrence of bradycardia or hypotension (11\% of the patients). Drug interactions that could alter the patients' blood glucose or electrolyte households were identified in $6 \%$ of the patients. Other, less commonly occurring drug combinations could impact negatively on the neurological and muscular systems. Drug-drug interactions that favour urinary incontinence were not identified. 


\section{Discussion}

\section{$\nabla$}

The present study reveals a high prevalence of drug consumption in general (83\%) and of polypharmacy in particular (38\%) among the female patients who presented to a specialist outpatient unit because of an overactive bladder syndrome. $57 \%$ of all patients took drugs that could favour urinary incontinence.

The generally high prevalence of drug consumption is in accord with the age structure of the patients, $55 \%$ of whom were 60 or more years old. Also in a large French cross-sectional analysis of 974 female nursing home residents, age was found to be an independent risk factor for polypharmacy and inappropriate drug prescription practices [33].

It is of interest, however, that $57 \%$ of the patients did indeed take drugs that could trigger or at least promote incontinence. The study of Kashyap et al. revealed a similar result whereby the prevalence of drug consumption with an impact on the lower urinary tract amounted to $61 \%$ [6].

This means that more than half of the patients regularly took one or more drugs that could, on their own, be the sole reason for their incontinence. It can thus be anticipated that discontinuation of the drug in question could result in a marked improvement of the incontinence or even to its cure.

It is thus probable that many patients would benefit from a reassessment of their need to take certain drugs and the discontinuation of not necessarily crucial drugs or their substitution by preparations with lower side effect profiles.

The pathomechanism that most frequently favoured incontinence was incomplete bladder emptying. On account of the frequency of consumption of drugs with just this side effect, it could be assumed that the syndrome of overflow bladder ought to be common in this collective. However, only two of the 765 analysed patients suffered from an overflow bladder and were thus excluded from the study in accordance with its exclusion criteria. A possible reason for the low number of patients with an overflow bladder in our collective is the fact that this clinical entity is often primarily evaluated by urologists.

$38 \%$ of all patients and thus more than a third of them took five or more drugs daily and therefore fulfilled the criterion for polypharmacy. This result agrees with the findings of Maher et al., who in their study on the clinical consequences of polypharmacy assumed that $36 \%$ of the women in an outpatient setting regularly took more than five drugs for longer periods of time [7]. Since it must be assumed that the compliance for drug consumption among elderly patients is reduced [34], the actual incidence of polypharmacy could be lower. This would mean a certain degree of protection for the patients.

Worthy of note is that almost half of the patients (45\%) took drugs that could in combination trigger harmful interactions. Almost one fifth of them (17\%) took drugs that could potentially lead to three or more harmful interactions.

The homogeneity of the patient collective can be considered as a strength of this study because they were all treated in a specialist outpatient unit of a university hospital. Furthermore the drug history was documented in detail and subject to a personal, non-automatic, inspection.

One limitation of the present study is the fact that no conclusion can be drawn about a relationship between drug consumption and other forms of urinary incontinence such as strain urine incontinency and bladder emptying disorders with or without incontinence.
A further question that remains unanswered by this study is about the actual incidence of the urinary incontinence-promoting side effects of the evaluated drugs.

\section{Practical Conclusions \\ $\nabla$}

This study underlines the importance of a critical confrontation with polypharmacy. Polypharmacy is a frequent phenomenon in our society and harbours the risk of illness though over-therapy. In the course of the clarification of urinary incontinence in women, a complete coverage of drug consumption is indispensable. Since many drugs can trigger or promote urinary incontinence, it may be assumed that a discontinuation of the drug in question could lead to an improvement of the incontinence or even to its cure. The omission of a specific drug is, however, often not possible because the drug was prescribed for an important indication. Over-therapy and undesired side effects can only be reduced by a regular inspection of indications and doses in close interdisciplinary cooperation between general practitioners and specialists.

\section{Conflict of Interest}

None.

\section{References}

1 Resnick NM. Urinary incontinence. Public Health Rep 1987; 102 (4 Suppl.): 67-70

2 Milsom I, Abrams P, Cardozo L et al. How widespread are the symptoms of an overactive bladder and how are they managed? A populationbased prevalence study. BJU Int 2001; 87: 760-766

3 Hannestad YS, Rortveit G, Sandvik $\mathrm{H}$ et al. A community-based epidemiological survey of female urinary incontinence: The Norwegian EPINCONT Study. J Clin Epidemiol 2000; 53: 1150-1157

4 Lee YS, Lee KS, Jung JH et al. Prevalence of overactive bladder, urinary incontinence, and lower urinary tract symptoms: results of Korean EPIC study. World J Urol 2009; 29: 185-190

5 Nabi G, Cody JD, Ellis G et al. Anticholinergic drugs versus placebo for overactive bladder syndrome in adults. Cochrane Database Syst Rev 2006; (4): CD003781

6 Kashyap M, Tu L, Tannenbaum C. Prevalence of commonly prescribed medications potentially contributing to urinary symptoms in a cohort of older patients seeking care for incontinence. BMC Geriatr 2013; 13 : 57

7 Maher RL, Hanlon J, Hajjar ER. Clinical consequences of polypharmacy in elderly. Expert Opin Drug Saf 2014; 13: 57-65

8 Ruby CM, Hanlon JT, Boudreau RM et al. The effect of medication use on urinary incontinence in community-dwelling elderly women. J Am Geriatr Soc 2010; 58: 1715-1720

9 Medeiros-Souza P, Santos-Neto LL, Kusano LT et al. Diagnosis and control of polypharmacy in the elderly. Rev Saude Publica 2007; 41: 10491053

10 Abrams P, Cardozo L, Fall M et al. The standardisation of terminology in lower urinary tract function: report from the standardisation subcommittee of the International Continence Society. Urology 2003; 61: 37-49

11 Petri E, Kölbl H, Hrsg. Gynäkologische Urologie - Interdisziplinäre Diagnostik und Therapie. 4. vollständig überarbeitete Auflage. Stuttgart: Thieme; 2013

12 Füsgen I, Hrsg. Der ältere Patient - Problemorientierte Diagnostik und Therapie. 2. Aufl. München, Wien, Baltimore: Urban \& Schwarzenberg; 1996: 282-305

13 Thorpe M. Overactive bladder: the importance of tailoring treatment to the individual patient. J Multidiscip Health 2011; 4: 233

14 Böhmer F, Füsgen I, Hrsg. Geriatrie - Der ältere Patient mit seinen Besonderheiten. Wien, Köln, Weimar: Böhlau Verlag; 2008: 167-173 
15 Ekundayo OJ, Markland A, Lefante C et al. Association of diuretic use and overactive bladder syndrome in older adults: a propensity score analysis. Arch Gerontol Geriatr 2009; 49: 64-68

16 Marshall HJ, Beevers DG. Alpha-adrenoceptor blocking drugs and female urinary incontinence: prevalence and reversibility. $\mathrm{Br} J$ Clin Pharmacol 1996; 42: 507-509

17 Österreichische Gesellschaft für Geriatrie und Gerontologie. Broschüre: Polypharmazie. Wien: Österreichische Gesellschaft für Geriatrie und Gerontologie; 2013: 55

18 Deutsche Gesellschaft für Allgemeinmedizin und Familienmedizin. Degam Leitlinie-Harninkontinenz 5 [Internet]. 2004. Online: http:// www.degam.de/files/Inhalte/Leitlinien-Inhalte/Dokumente/DEGAMS3-Leitlinien/LL-05_Inkontinenz-002.pdf; last access: 01.03.2016

19 Menefee SA, Chesson R, Wall LL. Stress urinary incontinence due to prescription medications: alpha-blockers and angiotensin converting enzyme inhibitors. Obstet Gynecol 1998; 91 (5 Pt 2): 853-854

20 Hall SA, Yang M, Gates MA et al. Associations of commonly used medications with urinary incontinence in a community based sample. J Urol 2012; 188: 183-189

21 Hendrix SL, Cochrane BB, Nygaard IE et al. Effects of estrogen with and without progestin on urinary incontinence. JAMA 2005; 293: 935-948

22 Culligan PJ, Heit M. Urinary incontinence in women: evaluation and management. Am Fam Physician 2000; 62: 2433-2444, 2447, 2452

23 Finkelstein MM. Medical conditions, medications, and urinary incontinence. Analysis of a population-based survey. Can Fam Physician 2002; 48: 96

24 Tonini M, Candura SM. 5-HT4 receptor agonists and bladder disorders. Trends Pharmacol Sci 1996; 17: 314-316

25 Hall SA, Maserejian NN, Link CL et al. Are commonly used psychoactive medications associated with lower urinary tract symptoms? Eur J Clin Pharmacol 2012; 68: 783-791
26 Clearinghouse TNNK and UDI. Urinary Retention [Internet]. [zitiert 23. Juli 2014]. Online: http:/http://kidney.niddk.nih.gov/kudiseases/ pubs/UrinaryRetention/\#sec3; last access: 01.03.2016

27 Kiss G. Medikamente und ihre Interaktionen, die die Inkontinenz fördern oder verhindern. J Für Urol Urogynäkologie [Internet]. 2006. Online: http://www.kup.at/kup/pdf/5947.pdf; last access: 01.03.2016

28 Hashimoto M, Imamura T, Tanimukai S et al. Urinary incontinence: an unrecognised adverse effect with donepezil. Lancet 2000; 356: 568

29 Steele AC, Walsh P, Bentley $M$ et al. A randomized, double-blind placebo-controlled trial of the effects of the 5-hydroxytriptamine(4) agonist cisapride on the female urinary bladder. Am J Obstet Gynecol 2001; 185: 62-64

30 de Boer TA, Slieker-ten Hove MCP, Burger CW et al. The prevalence and risk factors of overactive bladder symptoms and its relation to pelvic organ prolapse symptoms in a general female population. Int Urogynecol J 2011; 22: 569-575

31 Abrams P, Cardozo L, Fall M et al. The standardisation of terminology in lower urinary tract function: report from the standardisation subcommittee of the International Continence Society. Urology 2003; 61: 37-49

32 Asplund R, Johansson S, Henriksson S et al. Nocturia, depression and antidepressant medication. BJU Int 2005; 95: 820-823

33 Cool C, Cestac P, Laborde C et al. Potentially inappropriate drug prescribing and associated factors in nursing homes. J Am Med Dir Assoc 2014; 15: 850

34 Murray MD, Morrow DG, Weiner M et al. A conceptual framework to study medication adherence in older adults. Am J Geriatr Pharmacother $2004 ; 2: 36-43$ 